\title{
"BIOETHICS: BRIDGE TO THE FUTURE" (1971) BY POTTER VR AS AN INTELLECTUAL MANIFESTO: TO THE 50TH ANNIVERSARY OF THE BOOK RELEASE
}

\section{Firsov DE $\otimes$}

Yaroslavl State Medical University, Yaroslavl, Russia

This article analyzes the book "Bioethics: Bridge to the Future" by Potter VR as a personal message, a manifesto of an intellectual, a display of spiritual search against the backdrop of a crisis of ideologies, then looks into the factors that shaped the bioethical concept and establishes the significance this work and the bioethical concept have in the 21 st century.

Key words: bioethics, Potter VR, intellectuals, "creative class", responsibility.

$\square$ Correspondence should be addressed: Denis E. Firsov

Revolutsionnaya, 5, Yaroslavl region, Yaroslavl, 150000, Russia; f300670@mail.ru

Received: 21.05.2021 Accepted: 28.05.2021 Published online: 30.06.2021

DOI: $10.24075 /$ medet.2021.015

\section{“ВIOETHICS: BRIDGE TO THE FUTURE” (1971 Г.) В. Р. ПОТTЕРА КАК ИНТЕЛЛЕКТУАЛЬНЫЙ МАНИФЕСТ: К 50-ЛЕТИЮ ВЫХОДА КНИГИ}

Д. Е. Фирсов

Ярославский государственный медицинский университет, Ярославль, Россия

В статье анализируется книга "Вioethics: Bridge to the Future" В. Р. Поттера как личное послание, манифест интеллектуала, проявление духовного поиска в условиях кризиса идеологий. Рассматриваются факторы формирования биоэтической концепции. Определяется значение работы В. Р. Поттера и биоэтической концепции в XXI в.

Ключевые слова: биоэтика, В. Р. Поттер, интеллектуалы, «креативный класс», ответственность.

$\bowtie$ Для корреспонденции: Фирсов Денис Евгеньевич

ул. Революционная, д. 5, Ярославская область, г. Ярославль, 150000, Россия; f300670@mail.ru

Поступила: 21.05.2021 Статья принята к печати: 28.05.2021 Опубликована онлайн: 30.06.2021

DOI: $10.24075 /$ medet.2021.015

In 2021, "Bioethics: Bridge to the Future", a book by Potter VR, turns 50 [1]. Despite the fact that the author himself stated the materials from the book were first published in 1962 ( $\mathrm{p}$. 7) [1], and regardless of the debate around the precedence of use of "bioethics", a key concept, the book of 1971 is undoubtedly one of the keynote works that establishes the idea and conceptual meaning of bioethical categories.

The process of rethinking and updating of bioethical principles in theoretical and applied science, in social practice, including the aspects of economic processes, political decisions, is permanent, focused on the needs of an evolving society that adapt to the current situation. Certain aspects of the bioethical approach undergo critical analysis [2], but in general, its relevance in the real world of the 20th and early 21 st centuries is not questioned.

There is obviously every reason to consider the bioethical strategy as a new sociocultural paradigm of its time [3]. Indeed, the fairness and the degree of influence of bioethical principles on the social processes of the 20th and early 21 st centuries allow characterizing the V. R. Potter's concept not only as an important stage in understanding the eternal questions of collation of the nature's resources and civilization's capacity, that of the world and the human being, but also view those principles as a socio-cultural phenomenon of that age.

Numerous studies have been published to date [2], but the work of V. R. Potter can be considered in the light of a yet another socio-cultural aspect. This article analyzes the book "Bioethics: Bridge to the Future" as a personal message, a manifesto of an intellectual, a display of spiritual search against the backdrop of a crisis of ideologies.

There are two factors that are rightfully viewed as historical conditions in which the bioethical concept was formed:

1) As a conceptual (in the broadest sense, moral) system, bioethics emerged when the crisis of axiological guidelines, which happened in middle of the 20th century, was gradually subdued, and there was a need for the most critical rethinking of the obvious and dramatic devaluation of what the European community held as its values.

The significance of the dramatic events of the 20th century, as perceived by Potter VR, is reflected in the book. This reflection includes the emotional description of nature in terms typically associated with the post-war chaos, and the didactic connotation of the concept of "dangerous knowledge" linked to the deployment of poisonous gases during World War 1 (pp. 35, 67) [1].

2) Bioethical strategy was formed when the civilization was rapidly advancing technologically, the boundaries of the humanity's potential were boldly and "futuristically" reassessed, human kind was ready to make smaller steps forward and then leap into the future. Deontological stereotypes of the turn of the 19th and 20th centuries were obviously archaic; they nostalgically reanimated the formal continuity of values in the scientific community, but objectively did not reflect the current trends in the development of science and civilization. Thus, there was a need for a new look at the problem of balance of "facts" and their "meaning", the dissonance between "goaldriven ethics" and "means-conscious ethics." The book by V. R. Potter is full of the relevant ideas. 
But, in addition to these undoubtedly objective factors, the background against which bioethics was developing contained another influential component that usually escapes the attention of researchers, although it was largely generated by the same historical circumstances. Sixties and seventies of the 20th century were the heyday of European (and Western, in a broad sense) intellectual culture. All the media allowing to express oneself back then, from academic and avant-garde literature to cinema that was mastering new means of expression, were actively used by Western intellectuals as a space for creative self-identification, a platform allowing to manifest the new values: aesthetic, humanistic, ethical [4]. "Future" was one of the most popular topics at that time (p. 7) [1].

V. R. Potter himself saw the book as the result of rethinking of personal and professional ("30 years of cancer research") intellectual experience. The "Bioethical Creed for Individuals" (pp. 5-7, 209) [1], a kind of synopsis of Potter's ideas, highlights the "personal message" side of the book's nature especially strongly (pp. 5-7, 209) [1].

Potter VR formulates his task as an attempt to "understand the nature of man and his relationship to the world." To get this understanding, "humanity urgently needs new wisdom, which would be "knowledge about how to use knowledge" for survival of an individual and improvement of his life" (p. 9) [1]. That is, from a formal point of view, V. R. Potter proposes a universal methodology, a way to support implementation of the progress ethics standard from an epistemological perspective.

But for all the declared universality of bioethical methodology, it is not democratic. "The fate of the world," writes V. R. Potter, "depends on the continued integration and expansion of the knowledge held by a relatively small number of people." This means that bioethical axiology focuses on a special actor of cognition, a type of intellectual Potter calls "survivalists". According to him, they come from academic environments and share the specific trait of being especially concerned with the problem of mankind's survival (pp. 10, 164) [1].

It should be noted that V. R. Potter's description of the community of intellectuals and the specifics of their activity closely resembles the concept of "creative class", which is widespread in the American historical tradition. Generalizing the parameters of this approach, R. Florida (George Mason University Schar School of Policy and Government) stated that the "core of the creative class" includes holders of competencies in various scientific and technological spheres, in "architecture, design, education, art, music and entertainment... the creative class also includes a large group of creative professionals working in business and finance, law and healthcare and the related fields" [5].

The overall socio-economic function of the "creative class" generally seconds the tasks Potter VR saw before the community of intellectuals described in his book. He agrees with D Lilienthal's requirements that are "universal" for all fields of activity: the ability to imagine (creativity as it is), independent thinking, factual perception of the reality, "intellectual independence combined with the ability to accept criticism and analysis of the results by other specialists", scientific universalism, scientific viability. "The path to wisdom," as Potter VR notes, "runs through a consensus reached in interdisciplinary groups." For him, freedom of creativity for is one of the problems of urbanization (pp. 59-61, 76) [1]

The tasks set before the "creative class" are "design" or "creation of new ideas, new technologies and new creative content", "solution of complex problems." The hallmarks of an intellectual here are "significant independence of thought, a high level of education and human capital ... creativity, individual characteristics and personal merit." This approach, according to R. Florida's calculation, allows listing 38 million people, which is about 30\% of all working Americans, into the "creative class" [5].

It should be noted that the "broad" approach to the reproduction of intellectual environment adopted in the "creative class" theory compensates for the dissonance created by the "exclusivity" and the extended list of tasks set before the community of intellectuals Potter VR appeals to.

The appeal to the need to synthesize the creative and ethical potential of intellectuals and the power resource is also traditional for intellectual manifestation [4]. Stating that "the age-old question of the nature of man and his relationship with the world becomes more and more important in view of the last three decades of our century ... when political decisions are made without accounting for biological knowledge", Potter VR develops the idea of the need to influence political processes and power wielded by groups competent in natural science and humanitarian knowledge. According to V. R. Potter, "the attitude of society to a specialist and the attitude of an intellectual to his role in the society" are two current problems (pp. 12, 88, 161) [1].

V. R. Potter characterizes himself as an "adept of the mechanistic theory", "a pragmatic mechanist". At the same time, he finds it important to prevent the premature conclusion that the mechanical explanation of the world cancels teleological meaning of the development [6]. Criticizing teleology of Teilhard de Chardin relying on the "strict sequential mechanicalism" of 12 "paradigms of mechanistic biology," V. R. Potter believes that "a mechanist never doubts that all the facts unknown today will be discovered and explained in the future." In other words, the actuality of mechanistic teleology is not a paradox for him, as is the possibility of combining the concepts of "personality" and "cybernetic machine" in the characteristics of a person (pp. 19, 22-31, 39-49, 126) [1].

From the standpoint of the comparative ideological maturity of the 21st century, it is possible to criticize the sophistic nature of Potter's VR appeal to "wisdom" (regardless of who wields it, be it intellectuals with their "exclusive wisdom", specialists with "competent wisdom or the masses with the wisdom of fatal inevitability) and the path of evolving ideological compromise that it opens. However, it is obvious that the practical value of bioethical appeal to "wisdom" is disavowed by the indication of the possibility of transition ("Bridge") to a new biological and ethical rationality, marking the only productive way to overcome conservatism. In this sense, bioethics is a declaration of humanistic rationalism ("realism") seeking to mobilize a person's spiritual potential and aiming to push this person to his/her moral maximum.

The Creed, which concludes Potter's VR book, is an element of a slightly naive but touching attempt at immortalization: the author hopes that descendants "will remember him with gratitude" (p. 209) [1]. This phrase expresses perhaps the most important thesis of the book — trust in the person of the future. It is the trust in man, his mind and spiritual integrity that ensured the stability of bioethical approach in determining capabilities of science and technology employed to solve urgent problems the society faced in the 20th century. This trust remains as important in the 21st century [7].

Assessing the book by Potter VR, it is important to note that he avoids one of the specific temptations of intellectuals and abstains from condemning imperfections of the world and calling for an individual "fight against evil", which would have represented the vigilante fixation popular in American culture. 
Today, bioethics is a reminder that humanistic freedom is ensured by humanistic responsibility. According to Potter VR, "cultural evolution would have been very slow if it were not for the persistent desire of a person to introduce something new into his life and to not follow instructions to the letter." This "new" is introduced into the soil of bioethics, when in certain areas of science there is a deficit ("crisis") of methodology that factors in the general ethical aspects of medical research [8]; it is also behind introduction of the new theoretical categories [9], the ways of practical application bioethical principles [7; 10].

Behind its primary significance, Potter's VR book is the personal message of an intellectual, a declaration that reflects the dialectics of a time of great hopes and equally great threats, when everyone is responsible for the future of the world [1]. This message to humanity continues to gather different assessments, which means that it is still relevant for civilization.

\section{References}

1. Potter VR. Bioethics: Bridge to the Future. 2002; 216 c. Russian.

2. Letov OV. Problems and Principles of Bioethics. Human: Image and essence. Humanitarian aspects 2017; 3-4 (30-31): 189-199. Russian.

3. Ketova TN. Bioethics as a stage in deveiopment of humanism. Uchenye zapiski SPbGMU. 2015; 4: 31-34. Russian.

4. Firsov DE. European Inteiiectualism: Sociocultural Strategy. Yaroslavl. 2012; 86, 94-117. Russian.

5. Florida R. Creative class: people who change the future. Moscow 2005; 23-24. Russian.

6. Chelpanov G. Introduktion to philosophy. Kiev 1907; 387. Russian.

7. Tomashov VV, Firsov DE. Processual bioethical model of professional loability. Demidov Yaroslavl State University, 2018; 392-394. Russian.

8. Semenova NV, Grachev GI. Philosophy of treatment and treatment of philosophy. Meditsinskaya Ethica [Medical Ethics] 2020; (1): 4-7. Russian.

9. Moiseev VI. Bioethics is the science of bioeths. Dufficult Patient 2017; 1: 55-58. Russian.

10. Firsov DE. The competency-based approach to high-tech research in the teaching of bioethics. Meditsinskaya Ethica [Medical Ethics] 2020; (1): 12-14. Russian.

\section{Литература}

1. Поттер В. Р. Биоэтика: мост в будущее. 2002; 216 с.

2. Летов О. В. Проблемы и принципы биоэтики. Человек: образ и сущность. Гуманитарные аспекты. 2017;3-4 (30-31): 189-199

3. Кетова Т. Н. Биоэтика как этап развития гуманизма. Ученые записки СПбГМУ им. Акад. И. П. Павлова. 2015;22(4): 33

4. Фирсов Д. Е. Европейский интеллектуализм: социокультурная стратегия. Ярославль. 2012; 86, 94-117.

5. Флорида Р. Креативный класс: люди, которые меняют будущее. М., 2005; 23-24 с.

6. Челпанов Г. Введение в философию. Киев, 1907; 387 с.

7. Томашов В. В., Фирсов Д. Е. Процессуальная биоэтическая модель реализации профессиональной ответственности.

Актуальные проблемы совершенствования высшего образования: Материалы XIII научно-методической конференции с международным участием. Ярославль: Ярославский государственный университет им. П. Г. Демидова, 2018; 392-394.

8. Семенова Н. В., Грачев Г. И. Философия врачевания и врачевание философии. Медицинская этика. 2020;1: 4

9. Моисеев В. И. Биоэтика - наука о биоэтах. Трудный пациент. 2007; 5.(1): 55-58

10. Фирсов Д. Е. Вопросы компетентностного подхода при высокотехнологичных исследованиях в преподавании биоэтики. Медицинская этика. 2020;1: 12-14 